\title{
Winter flounder Pseudopleuronectes americanus reproductive success. II. Effects of spawning time and female size on size, composition and viability of eggs and larvae
}

\author{
L. J. Buckley, A. S. Smigielski, T. A. Halavik, E. M. Caldarone, B. R. Burns, \\ G. C. Laurence
}

National Marine Fisheries Service, Northeast Fisheries Center, Narragansett Laboratory, Narragansett, Rhode Island 02882-1199, USA

\begin{abstract}
Vital statistics and embryo and larval viability were determined for winter flounder Pseudopleuronectes americanus spawning in Narragansett Bay, Rhode Island, USA, over the course of the spawning season. Fish approaching spawning condition were collected throughout the spawning season and hand-stripped in the laboratory. Larvae were reared through the first month of life. Female size affected most of the reproductive parameters examined, including both absolute and relative measures of total reproductive output (reproductive rate and gonadosomatic index), egg size, fecundity, and viability. Spawning time was found to affect egg size, fecundity, and viability, but not reproductive rate or gonadosomatic index. Egg size increased with increasing female size and decreased as the spawning season progressed. Spawning time and female size explained $61 \%$ of the observed variability in egg size among females. Female size explained $95 \%$ of the variability in reproductive rate and $90 \%$ of the variability in fecundity. Female size and spawning time combined explained $94 \%$ of the variablity in fecundity. The effects of female size and spawning tume on both fertility and hatch rate were non-additive. Embryos produced earlier in the spawning season appeared to have a survival advantage over those produced later in the spawning season. Embryos produced by small, latespawning fish appeared to be at a pronounced disadvantage.
\end{abstract}

\section{INTRODUCTION}

High fecundity and high mortality during early life stages are characteristic of temperate marine fishes. Individuals that survive to reproduce are the rare exceptions. Much effort has recently been devoted to determining the role of the environment in the success or failure of larval cohorts and individuals. Less effort has been directed towards study of the role of intrinsic or innate biotic factors related to parental investment in gametes and the trade-off between the number and size of eggs produced. The existing body of literature suggests that egg size varies considerably among species, stocks and individuals (Hempel \& Blaxter 1967, Bagenal 1971, Miller et al. 1988). Both spawning time (Hempel \& Blaxter 1967, Bagenal 1971) and female size (Gall 1974, Kazakov 1981, Rogers \& Westin 1981, Zastrow et al. 1988) have been implicated as factors affecting egg size within a species. The com- bined effects of spawning time and female size have received little attention. While spawning time has been recognized as affecting egg size, its affect on fecundity has not been considered for most species.

In this paper we examine the effects of the size and age of spawning female winter flounder Pseudopleuronectes americanus, and of spawning time, on reproductive rate, fecundity, egg size, egg composition, and viability of eggs and larvae. The relations among these variables are also examined. This effort was prompted by our earlier observations of large differences in size of yolk-sac larvae among winter flounder spawning at different locations and of a relationship between size of yolk-sac larvae and survival for the first month of life (Buckley et al. 1991).

We describe a practical approach to determining reproductive rate, gonadosomatic index (GSI), egg size, and fecundity of individual fish while studying egg and larval viability on the same individuals 


\section{METHODS}

A site in upper Narragansett Bay north of Prudence Island, Rhode Island, USA, was chosen for intensive study of fish spawning over the duration of the spawning season. The site has been the subject of a major tagging program (State of Rhode Island, Department of Environmental Management) providing information on seasonal movements and maturation, and ready access to the large numbers of live fish necessary to obtain hydrating females over the entire spawning season. Mature winter flounder Pseudopleuronectes americanus were collected from January through March 1988. Females showing signs of hydration were selected from the catch. One collection of fish was also made in the lower West Passage of Narragansett Bay on 11 March 1988. Additional collections were made at the upper Narragansett Bay site in 1990.

Females were measured and weighed immediately before and after hand-stripping of eggs. The females were sacrificed after the second weighing and frozen. Subsamples of unfertilized eggs, taken for determination of dry weight and biochemical composition, were frozen at $-70^{\circ} \mathrm{C}$. Egg dry weight was determined by freezing eggs in a monolayer on the walls of a glass lyophilization vial. After freeze-drying, the individual eggs were easily separated and 20 intact eggs from each female were weighed individually to the nearest $0.1 \mu \mathrm{g}$ on a Cahn electro-balance. Larval dry weights (20 larvae, $3 \mathrm{~d}$ after hatch) and egg RNA, lipid and protein content were determined as described in Buckley et al. (1991). Because of the low concentration of DNA in unfertilized Pseudopleuronectes americanus eggs (Buckley 1980), this component was not measured. The ratio of dry weight to wet weight of unfertilized eggs was determined by weighing a group of several hundred eggs from each spawn before and after freeze-drying.

The remainder of the eggs were fertilized with the sperm from 3 males and incubated at $5^{\circ} \mathrm{C}$. Larvae were reared as described in Buckley et al. (1991) using the feeding regime described for 1988. Duplicate groups of 200 larvae each from individual females were reared for $28 \mathrm{~d}$ in $36 \mathrm{l}$ tanks. After initial inoculation with $1 \mathrm{l}$ of a dense culture of algae Tetraselmis sp., larvae were fed cultured rotifers Brachionus plicatilis at the rate of 2000 rotifers $\mathrm{l}^{-1} \mathrm{~d}^{-1}$. A volume of culture corresponding to 72000 rotifers was concentrated on a sieve and added to each tank $6 \mathrm{~d} \mathrm{wk}^{-1}$. After completion of the $28 \mathrm{~d}$ rearing period, tanks were drained and survivors were counted, measured and weighed

Fertilization rate was estimated 24 h after spawning

- Reference to trade names does not imply endorsement by the United States Government by selecting 100 eggs at random and counting, under a dissecting microscope, the number showing signs of cleavage. A group of 100 cleaving embryos were incubated in a $200 \mathrm{ml}$ tube fitted with a Nitex mesh bottom set in a $36 \mathrm{l}$ tank. Two days after hatching was completed the number of larvae and dead eggs was counted. Hatch rate was defined as the total number of larvae counted, and viable hatch as the number of active, free-swimming larvae showing no obvious abnormalities. Abnormalities observed included lordosis, scoliosis and larvae with their heads still inside the chorion.

Otolith and scale samples were taken from the female winter flounder after partial thawing. Fish ages were determined by counting the number of annual rings on several representative scales. The ovaries were removed, refrozen, freeze-dried and weighed to the nearest milligram. In 1990 several winter flounder were hand-stripped and weighed live, as above, and then returned to the holding tanks. These fish rehydrated and spawned 1 or 2 additional times. When the females appeared to be completely spent they were sacrificed and the ovaries treated as described above.

Data analysis was done using SAS System software for personal computers (SAS Institute Inc. 1985). Square root transformation was applied to percent survival values [(survival +0.5$)^{1 / 2}$ ] and arcsine transformation applied to fertilization and viable hatch rates [arcsine $(\% / 100)^{1 / 2}$ ] prior to analysis of variance and regression analysis. For analysis of variance, fish were assigned to size and spawning date groups. Females were assigned to 1 of 3 size groups as follows: small (total length $<295 \mathrm{~mm}$ ); medium (total length 295 to $326 \mathrm{~mm}$ ); large (total length $>326 \mathrm{~mm}$ ). Females were assigned to 1 of 2 spawning date groups depending upon when they spawned in relation to peak spawning, which was estimated to have occurred in upper Narragansett Bay the first week of March 1988 (J. Christopher Powell pers. comm.). Fish that spawned prior to $7 \mathrm{March}$ were assigned to the early spawning group; fish that spawned after that date were assigned to the late group.

\section{RESULTS}

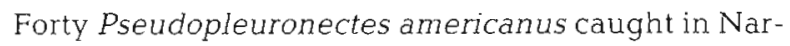
ragansett Bay were spawned by hand-stripping between 1 February and 11 April 1988. The spawning females ranged in size from 250 to $396 \mathrm{~mm}$ total length and from 240 to $1016 \mathrm{~g}$ in weight (Table 1). The relation between total length and wet weight just prior to spawning is given in Table 2. Scale analysis indicated at least 4 yr classes, with 3, 4, and 5 yr old fish predominating. No trend over time was observed in the size or age of fish spawned during the study. No signifi- 
cant correlation was observed between female size or age and spawning date. No significant difference was observed in either the mean spawning dates of small, medium and large females or the mean size of earlyand late-spawning fish.

\section{Reproductive rate and GSI}

The wet weight of eggs obtained by a single handstripping ranged from a low of $36 \mathrm{~g}$ to a high of $144 \mathrm{~g}$. On average, 1 hand-stripping produced $69 \mathrm{~g}$ of eggs. Dissection of females after hand-stripping revealed that the ovaries of most fish still contained a large number of mature eggs. The total wet weight of the ovaries just prior to spawning was estimated from the weight of eggs obtained plus the weight of the remaining ovary after hand-stripping. This number when expressed on a yearly basis $\left(\mathrm{g} \mathrm{Yr}^{-1}\right)$ is the reproductive rate (Ware 1985). The weight of eggs spawned, the remaining ovarian weight and the total ovarian weight all increased with female size (Fig. 1) and were unaffected by spawning

Table 1. Pseudopleuronectes americanus. Size and reproductive data on winter flounder from Narragansett Bay, Rhode Island, USA. TL: total length. Ovary wet weight: estimated wet weight of the ovary just before spawning

\begin{tabular}{|c|c|c|c|c|c|}
\hline $\begin{array}{l}\mathrm{TL} \\
(\mathrm{mm})\end{array}$ & $\begin{array}{l}\text { Wet weight } \\
(\mathrm{g})\end{array}$ & $\begin{array}{l}\text { Spawning date } \\
\text { (Julian day) }\end{array}$ & $\begin{array}{l}\text { Ovary wet wt } \\
(\mathrm{g})\end{array}$ & $\begin{array}{l}\text { Egg dry wt } \\
(\mu . g)\end{array}$ & $\begin{array}{l}\text { Fecundity } \\
\text { (no. eggs) }\end{array}$ \\
\hline \multicolumn{6}{|c|}{ Upper Narragansett Bay } \\
\hline 294 & 430 & 32 & 118.4 & 50.2 & - \\
\hline 266 & 263 & 32 & 77.5 & 43.8 & - \\
\hline 295 & 352 & 32 & 91.3 & 46.2 & - \\
\hline 321 & 532 & 33 & 157.8 & 54.4 & - \\
\hline 372 & 669 & 45 & 207.8 & 47.3 & - \\
\hline 284 & 315 & 49 & 107.9 & - & - \\
\hline 381 & 774 & 49 & 281.6 & 54.4 & - \\
\hline 261 & 260 & 50 & 65.2 & 39.7 & - \\
\hline 292 & 286 & 50 & 68.5 & 43.4 & - \\
\hline 315 & 373 & 51 & 82.5 & 54.0 & 192240 \\
\hline 374 & 802 & 52 & 335.6 & 54.2 & 1035653 \\
\hline 250 & 240 & 53 & 66.9 & 45.9 & 222491 \\
\hline 351 & 580 & 56 & 188.3 & 43.8 & - \\
\hline 290 & 351 & 57 & 105.9 & 41.0 & - \\
\hline 298 & 397 & 84 & 103.8 & 38.9 & - \\
\hline 334 & 597 & 85 & 188.0 & 40.7 & 832196 \\
\hline 396 & 1016 & 85 & 368.1 & 48.7 & 1390495 \\
\hline 299 & 363 & 85 & 95.0 & 43.3 & - \\
\hline 282 & 306 & 87 & 100.2 & - & - \\
\hline 359 & 628 & 88 & 190.8 & 41.2 & 896455 \\
\hline 279 & 381 & 102 & 71.9 & 34.9 & - \\
\hline 320 & 440 & 41 & 116.8 & 51.1 & 369831 \\
\hline 314 & 461 & 47 & 146.8 & 47.3 & 568533 \\
\hline 324 & 430 & 49 & 108.6 & - & - \\
\hline 290 & 340 & 50 & 93.0 & 55.9 & - \\
\hline 318 & 465 & 53 & 144.0 & - & - \\
\hline 334 & 580 & 55 & 210.7 & - & - \\
\hline 350 & 573 & 56 & 191.0 & - & - \\
\hline 330 & 454 & 87 & 134.4 & 36.6 & 616280 \\
\hline 317 & 474 & 90 & 152.0 & 42.0 & - \\
\hline 300 & 427 & 90 & 139.4 & 38.2 & 614823 \\
\hline \multicolumn{6}{|c|}{ Lower West Passage } \\
\hline 390 & 930 & 72 & 322.7 & 47.9 & 1131404 \\
\hline 327 & 489 & 73 & 152.6 & 46.9 & 679486 \\
\hline 330 & 592 & 73 & 202.0 & 45.0 & 753385 \\
\hline 360 & 727 & 74 & 230.6 & 46.0 & 822999 \\
\hline 305 & 416 & 74 & 114.1 & 35.7 & 619677 \\
\hline 266 & 266 & 74 & 82.9 & 40.3 & 364602 \\
\hline 356 & 642 & 75 & 237.6 & 50.8 & 902800 \\
\hline 385 & 946 & 75 & 386.7 & 52.9 & - \\
\hline 304 & 406 & 77 & 135.4 & - & - \\
\hline
\end{tabular}


Table 2. Pseudopleuronectes americanus. Equations describing the relations among female size, spawning date, and reproductive effort of winter flounder from Narragansett Bay. ${ }^{a}$ GSI: gonadosomatic index

\begin{tabular}{|c|c|c|c|c|}
\hline Dependent variable $(y)$ & Equation & $\mathrm{n}$ & $r^{2}$ & $p>F$ \\
\hline Female weight $(g)$ & $\ln y=3.07$ ln Length -11.57 & 40 & 0.94 & 0.0001 \\
\hline Ovarine weight $(g)$ & $\begin{array}{l}y=0.420 \text { Weight }-50.5 \\
y=2.034 \text { Length }-492.4 \\
y=46.84 \text { Age }-54.5\end{array}$ & $\begin{array}{l}40 \\
40 \\
39\end{array}$ & $\begin{array}{l}0.95 \\
0.83 \\
0.60\end{array}$ & $\begin{array}{l}0.0001 \\
0.0001 \\
0.0001\end{array}$ \\
\hline GSI & $y=0.0164$ Weight +22.5 & 40 & 0.46 & 0.0001 \\
\hline Egg weight (mg) & $\begin{aligned} y= & -0.00016 \text { Spawn date }+0.0560 \\
y= & 0.000011 \text { Weight }+0.0397 \\
y= & -0.00020 \text { Spawn date } \\
& +0.000016 \text { Weight }+0.0503\end{aligned}$ & $\begin{array}{l}33 \\
33 \\
33\end{array}$ & $\begin{array}{l}0.31 \\
0.16 \\
0.61\end{array}$ & $\begin{array}{l}0.0008 \\
0.02 \\
0.001\end{array}$ \\
\hline $\begin{array}{l}\text { Fecundity } \\
\text { (eggs female }{ }^{-1} \text { ) }\end{array}$ & $\begin{aligned} y= & 1397 \text { Weight }-73780 \\
y= & 1324 \text { Weight }+4539 \text { Spawn } \\
& \text { date }-356002\end{aligned}$ & $\begin{array}{l}18 \\
18\end{array}$ & $\begin{array}{l}0.90 \\
0.94\end{array}$ & $\begin{array}{l}0.0001 \\
0.0001\end{array}$ \\
\hline
\end{tabular}

date. Female weight at spawning explained $95 \%$ of the variation in the reproductive rate (Table 2 ). The GSI [= (wet weight of eggs + wet weight of stripped ovary)/ (wet weight of female prior to spawning)] just prior to spawning also increased with increasing female size and was unaffected by spawning date (Table 2). The eggs obtained by a single hand-stripping represented between 22 and $84 \%$ of the total ovarian weight. The fraction of eggs spawned by a single hand-stripping decreased with increasing female size.

In 1990, 6 fish were spawned as described above but returned to holding tanks rather than sacrificed. These fish usually rehydrated and released eggs into the holding tank, or were hand-stripped 1 or 2 more times within several days of first spawning. The interval between spawns was typically 1 to $3 \mathrm{~d}$. When it appeared that the fish were completely spent, they were weighed, and the ovaries removed and processed

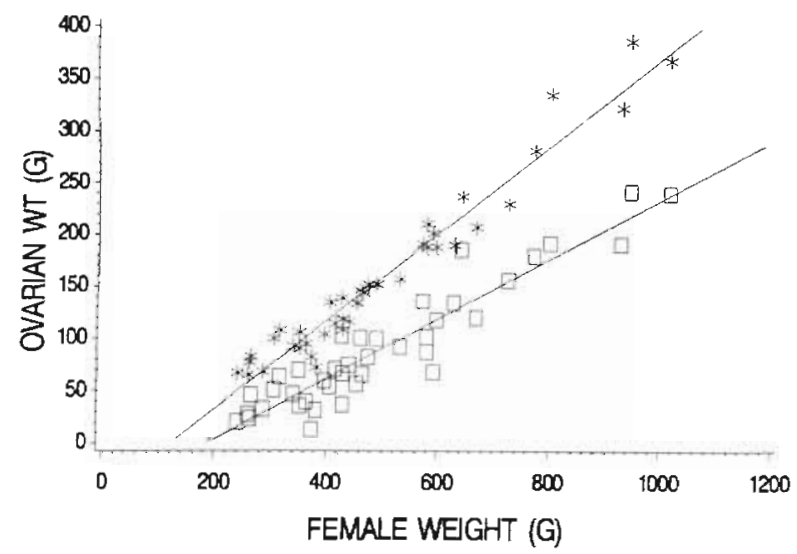

Fig. 1. Pseudopleuronectes americanus. Wet weight of ovary before $(x)$ and after $(\square)$ hand-stripping as described above. These spent ovaries contained very few mature eggs. The dry weight of the spent ovary represented on average $10.6 \%$ of the estimated dry weight of the ovary just prior to first spawning. The dry weight of the avary just prior to spawning was estimated by multiplying the difference between the wet weight of the fish just prior to the first spawning and the wet weight of the fish after the final spawning by the mean fraction dry weight of unfertilized eggs (0.161) and adding the dry weight of the spent ovary. Dry matter was $21.1 \pm 3.2 \%$ of the wet weight of the ovary after a single hand-stripping and $12.6 \pm 2.6 \%$ of the weight of the fully spent ovary.

\section{Egg weight and fecundity}

The mean dry weight of single eggs produced by individual winter flounder ranged from 35 to $56 \mathrm{ug}$ (mean $45.6 \pm 5.9, \mathrm{CV} 12.9 \%$; Table 1). Variability was considerably less among eggs produced by a given individual (average CV $7.2 \mathrm{~m}$ ). When a fish was handstripped more than once, mean egg dry weight decreased an average of $8 \%$ with each subsequent spawning.

Egg weight decreased as the spawning season progressed and increased with female size (Fig, 2). Together, female size and spawning date explained $61 \%$ of the variability in egg weight (Table 2). Analysis of covariance indicated significant differences $(p \leq 0.05)$ in mean egg weight between early-and latespawning fish after adjustment for differences in female size, and among female size groups after adjustment for spawning date (Table 3). Large, early-spawning fish produced the largest eggs while small, late- 
Fig. 2. Pseudopleuronectes americanus. Relation among female weight, spawning date, and egg weight of winter flounder

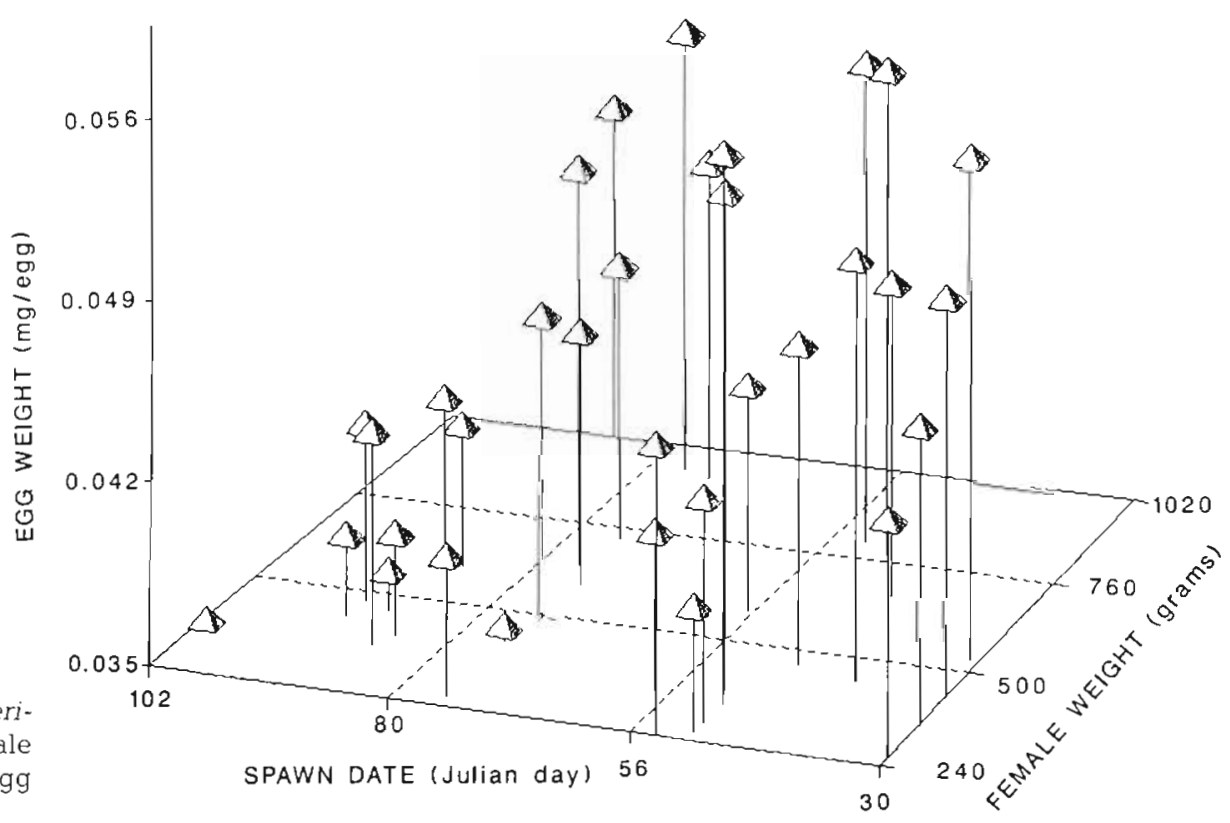

spawning females produced the smallest eggs. On average, dry matter represented $16 \%$ of the wet weight of Pseudopleuronectes americanus eggs.

Fecundity (b), the sum of the eggs obtained by handstripping plus the eggs remaining in the ovary, was estimated using the equation:

$$
b=\frac{\left[\left(w_{e} \times C\right)+\left(w_{o}\right)\right]}{m} \times 0.894
$$

where $w_{\mathrm{e}}$ is the wet weight of eggs obtained by handstripping, $w_{0}$ is the dry weight of the remaining ovary, $m$ is the dry weight of an individual egg and $C$ is the ratio of dry weight to wet weight of unfertilized eggs determined for each spawn. The term 0.894 is an estimate of the fraction of the ovarian dry weight actually made up of eggs just prior to spawning based on completely spent fish from 1990. Connective tissue, membranes, immature oocytes, and blood vessels make up the bulk of the remainder of the ripe ovary.

Fecundity increased with increasing female size (Fig. 3). For a given size of female, fecundity increased as the spawning season progressed due to the decrease in egg size. Female size and spawning date together explained $94 \%$ of the variability in fecundity (Table 2). Analysis of covariance indicated a significant difference $(p \leq 0.05)$ in mean fecundity between early-and late-spawning fish after adjustment for differences in female size. A significant difference $(p \leq 0.05)$ in mean fecundity was also observed among female size groups after adjustment for spawning date (Table 3 ).

Table 3. Pseudopleuronectes americanus. Mean values for egg weight and fecundity of Narragansutt Bay fish adjusted for spawning date and female size. ${ }^{a}$ Bracketed means are not significantly different ( $\geq 0.05$ ). LS mean: least-squares mean; SE: standard error

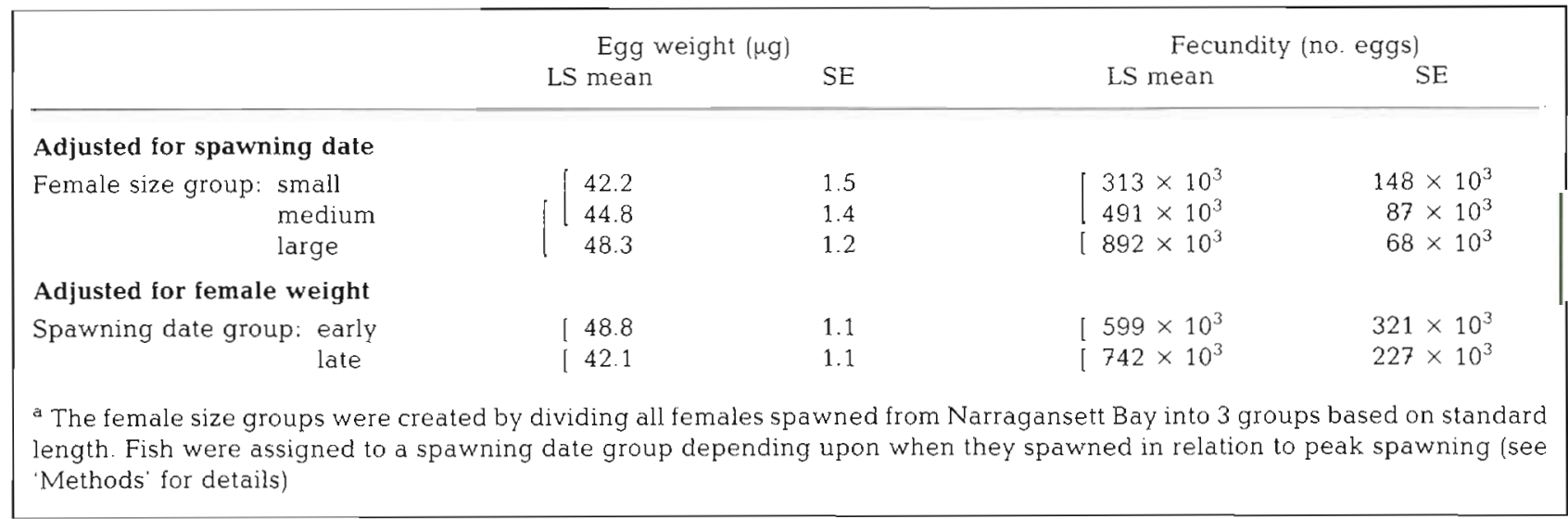




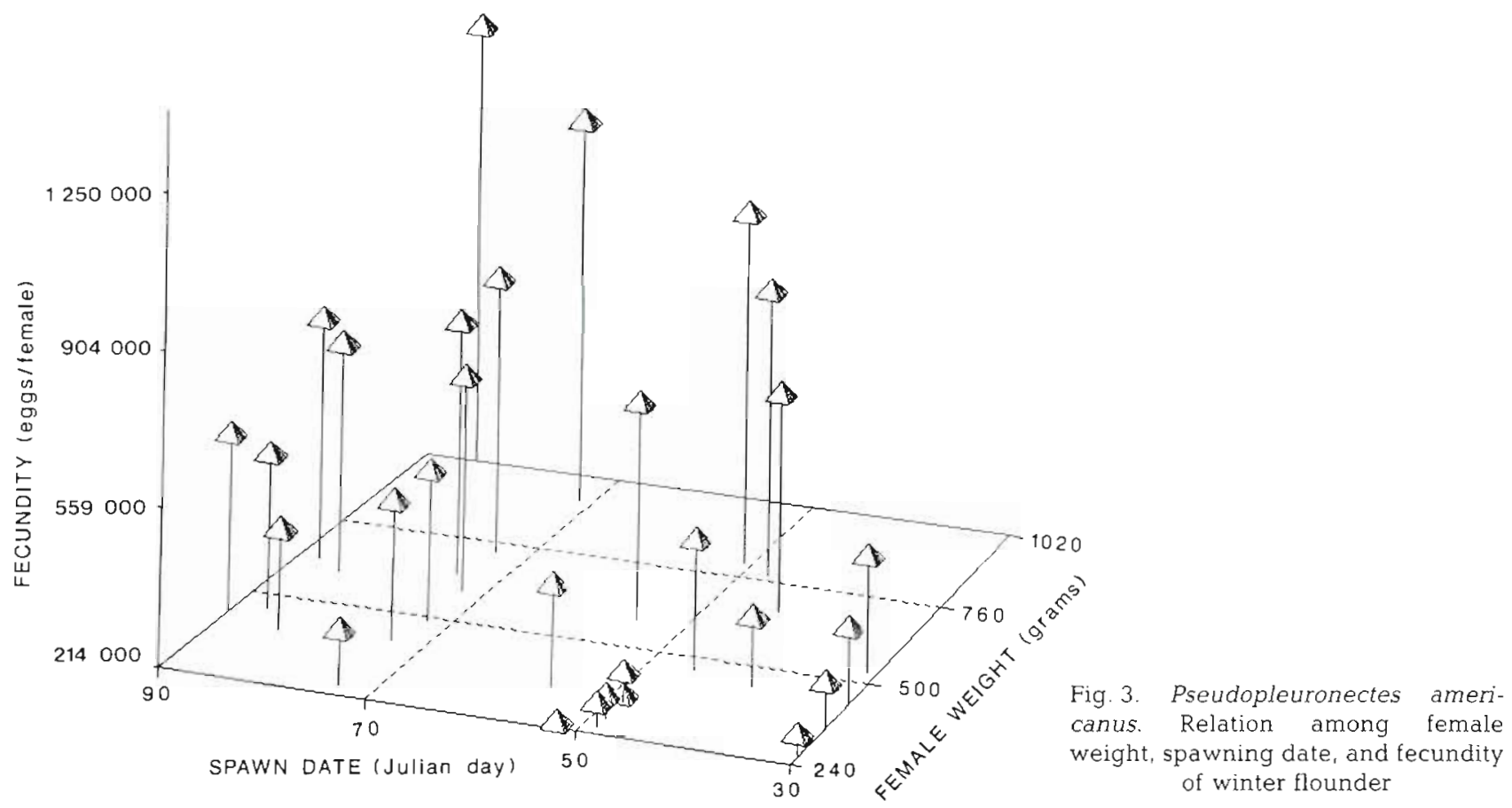

Biochemical composition of eggs

The protein, RNA and lipid composition of unfertilized Pseudopleuronectes americanus eggs are given as total content ( $\mathrm{gg} \mathrm{egg}^{-1}$ ) and concentration ( $\%$ dry weight) in Table 4 . The content of all 3 components was highly correlated with egg dry weight. Protein and lipid concentration were independent of egg size and spawning date. RNA concentration increased with date of spawning and decreased with egg size. Protein accounted for one-half of the dry weight of the egg

\section{Fertility, hatch, and survival (upper Narragansett Bay fish)}

To eliminate any possibility of the origin of fish affecting the viability of eggs and larvae, these analyses were limited to fish collected in upper Narragansett Bay in 1988. Analysis of variance of transformed data indicated a significant interaction $(p \leq 0.05)$ between female size and spawning time for fertility

Table 4. Pseudopleuronectes americanus. Biochemical composition of winter flounder eggs from Narragansett Bay

\begin{tabular}{lrr|}
\hline Component & $\begin{array}{c}\text { Content } \\
\left(\mu g \text { egg }^{-1}\right)\end{array}$ & $\begin{array}{r}\text { Concentration } \\
(\% \text { dry wt) }\end{array}$ \\
\hline Protein & $22.40 \pm 3.60$ & $50.0 \pm 4.6$ \\
RNA & $0.79 \pm 0.09$ & $1.8 \pm 0.1$ \\
Lipid & $5.58 \pm 0.87$ & $12.5 \pm 0.9$ \\
\hline
\end{tabular}

and viable hatch rates of winter flounder from upper Narragansett Bay (Table 5). No interaction was observed for larval survival rates. Fertility of eggs from different female winter flounder ranged from 31 to $99 \%$ with a mean of $91 \%$ Fertilization rates were lowest (mean $46 \%$ ) for small, late-spawning fish (Table $6)$. Viable hatch ranged from 0 to $96 \%$ with a mean of $74 \%$ and was again lowest (mean $22.5 \%$ ) for small, late-spawning fish (Table 6). Survival for the first month of life under standard conditions ranged from 0 to $9 \%$ with a mean of $2 \%$. Survival was higher for early-spawning fish $(2.6 \%)$ than for late spawners $(0.7 \%$ ) (Table 6$)$. Because of the low viable hatch of eggs from small, late-spawning fish no survival data were obtained for this group.

\section{Correlation among variables (upper Narragansett Bay fish)}

Most female winter flounder spawned within a few days of collection. This was anticipated since females showing signs of hydration were selected from the catch. An inverse correlation ( $p \leq 0.05)$ was observed between spawning date (Julian day) and the length of the embryonic period, although all eggs were incubated at the same temperature $\left(5^{\circ} \mathrm{C}\right)$. The length of time females were held in the laboratory prior to spawning was unrelated to any of the primary performance variables (fertility, viable hatch, and survival). Egg weight, larval length and larval weight were all correlated ( $p \leq 0.01$; Table 7 ). Fertility, hatch and viable hatch were highly correlated $(p \leq 0.0001)$ but unrelated 
Table 5. Pseudopleuronectes americanus. Analysis of variance for factors affecting fertility, viable hatch and survival of winter flourder eggs and larvae from upper Narragansett Bay. Where the interaction factor is significant no $F$ values are given for the other factors. Prior to ANOVA, fertilization and hatch rates were arcsine transformed, and survival was square-root transformed

\begin{tabular}{|c|c|c|c|c|c|}
\hline Variable & & Female size & Spawning date & Size $\times$ Date & Total \\
\hline Fertilization rate $(\%)$ & $\begin{array}{l}\mathrm{df} \\
F \text { value }\end{array}$ & $\begin{array}{l}2 \\
-\end{array}$ & $\begin{array}{l}1 \\
-\end{array}$ & $\begin{array}{l}2 \\
17.48 \cdots\end{array}$ & 30 \\
\hline Viable hatch $(\%)$ & $\begin{array}{l}\mathrm{df} \\
F \text { value }\end{array}$ & $\begin{array}{l}2 \\
-\end{array}$ & $\begin{array}{l}1 \\
-\end{array}$ & ${ }_{9.14}^{2} \ldots$ & 30 \\
\hline Survival (\%) & $\begin{array}{l}\mathrm{df} \\
F \text { value }\end{array}$ & $\begin{array}{l}2 \\
0.1\end{array}$ & $\begin{array}{l}1 \\
4.8\end{array}$ & $\begin{array}{l}1 \\
1.1\end{array}$ & 21 \\
\hline
\end{tabular}

Table 6. Pseudopleuronectes americanus. Fertilization, viable hatch, and survival rates (means \pm SD) of winter flounder eggs and larvae from upper Narragansett Bay. Where the interaction between female size group and spawning time group was not significant, main effects means were calculated and Tukey's studentized range effects applied to these values. Where the interaction was significant, simple main effects were tested. Values in a row with a letter in common or bracketed values in a column are not significantly different $(\mathrm{p} \geq 0.05)$. Prior to analysis of variance, fertilization and viable hatch rates were arcsine transformed. Survival rates were square-root transformed $\left[(x+0.5)^{1 / 2}\right]$. Numbers in parentheses represent number of observations per cell

\begin{tabular}{|c|c|c|c|c|}
\hline \multirow[t]{2}{*}{ Spawning group } & \multicolumn{3}{|c|}{ Female size group } & \multirow[t]{2}{*}{$\bar{x}$} \\
\hline & Small & Medium & Large & \\
\hline \multicolumn{5}{|c|}{ Fertilization rate $(\%)$} \\
\hline Early & {$\left[95.6 \pm 2.1(8)^{\mathrm{d}}\right.$} & $89.2 \pm 15.6(7)^{\mathrm{d}}$ & $95.7 \pm 4.4(6)^{a}$ & \multirow{2}{*}{$91.4 \pm 14.9$} \\
\hline Late & {$\left[46.0 \pm 21.2(2)^{b}\right.$} & $97.5 \pm 1.3(4)^{\mathrm{d}}$ & $96.5 \pm 1.3(4)^{a}$ & \\
\hline \multicolumn{5}{|c|}{ Viable hatch rate $(\%)$} \\
\hline Early & {$\left[72.1 \pm 3.9(8)^{\mathrm{a}}\right.$} & $63.1 \pm 29.5(7)^{\mathrm{a}}$ & $\left(83.5 \pm 6.2(6)^{a}\right.$ & \multirow{2}{*}{$74.0 \pm 22.3$} \\
\hline Late & {$\left[22.5 \pm 19.1(2)^{b}\right.$} & $90.5 \pm 2.5(4)^{\mathrm{d}}$ & {$\left[91.5 \pm 2.1(4)^{\prime \prime}\right.$} & \\
\hline \multicolumn{5}{|c|}{ Survival rate $(\%)$} \\
\hline Early & $2.1 \pm 1.4(5)$ & $2.2 \pm 2.2(5)$ & $3.8 \pm 4.1(4)$ & $2.6 \pm 2.6$ \\
\hline Late & - & $1.2 \pm 2.2(4)$ & $0.1 \pm 0.2(4)$ & $0.7 \pm 1.6$ \\
\hline $\bar{X}$ & $2.1 \pm 1.4^{\mathrm{a}}$ & $1.8 \pm 2.1^{\mathrm{a}}$ & $1.9 \pm 3.3^{\mathrm{a}}$ & $1.9 \pm 2.4$ \\
\hline
\end{tabular}

to larval survival (Table 7). The GSI was correlated with fertility, viable hatch and fecundity. The fraction of dry matter in the stripped ovary was correlated with fertility and viable hatch

Two estimators of the condition of the spawning females were calculated: a standard condition factor (Tyler \& Dunn 1976, Burton \& Idler 1984) and the residual GSI. Condition was defined as (female wet weight - ovarian weight)/length ${ }^{b}$, where $b$ is the exponent of the length-weight regression (Table 2). The residual GSI was defined as (actual GSI)-(GSI predicted from a regression between GSI and standard length).

No correlation was observed between these condition factors and performance variables (fertility, viable hatch, and larvalj. No correlation was observed between egg size or the concentration ( $\%$ dry wt) of any single class of biomolecule and egg viability as measured by fertilization, viable hatch or survival rates.

\section{DISCUSSION}

Our data on Pseudopleuronectes americanus from Narragansett Bay show that female size affected most of the reproductive parameters examined, including absolute and relative measures of total reproductive output (reproductive rate and GSI), egg size, fecundity, and viability. In concert with female size, spawning time was found to have an effect on egg size, fecundity and viability. Spawning time did not affect total reproductive output as measured by reproductive rate or GSI. The interaction of spawning time and female size was significant for fertilization rate and viable hatch but not for egg weight, fecundity or larval survival.

Female size was related closely to the absolute amount of mass directed toward reproduction. Of our 3 measures of the size and age of spawning females (length, weight and age), wet weight explained the largest part $(95 \%)$ of the variability observed in repro- 
Table 7 Pseudopleuronectes americanus. Correlation (r) among variables associated with reproduction of winter flounder from upper Narragansett Bay. Numbers in parentheses represent number of observations (GSI: gonadosomatic index)

\begin{tabular}{|c|c|c|c|c|c|}
\hline Variable & Fecundity & Egg weight & Fertility & Viable hatch & Survival \\
\hline Spawning date & $0.47^{*}(11)$ & $-0.65 \cdots(25)$ & $-0.26(31)$ & $0.14(31)$ & $-0.44^{\circ}(22)$ \\
\hline Female weight & $0.96 \cdots(11)$ & $0.31(25)$ & $0.16(31)$ & $0.37^{\circ}(31)$ & $-0.04(22)$ \\
\hline Female length & $0.87^{\cdots} \cdots(11)$ & $0.32(25)$ & $0.19(31)$ & $0.36 \cdot(31)$ & $0.03(22)$ \\
\hline Female age & $0.68^{*}(11)$ & $0.07(24)$ & $0.11(30)$ & $0.29(30)$ & $0.14(22)$ \\
\hline Female condition & $0.52(11)$ & $-0.11(25)$ & $-0.05(31)$ & $0.09(31)$ & $-0.26(22)$ \\
\hline GSI & $0.80^{\circ} \cdot(11)$ & $0.29(25)$ & $0.36^{\circ}(31)$ & $0.48^{\cdots}(31)$ & $-0.05(22)$ \\
\hline Residual GSI & $0.38(11)$ & $0.13(25)$ & $0.30(31)$ & $0.33(31)$ & $-0.10(22)$ \\
\hline Fraction of eggs spawned & $-0.57(11)$ & $0.03(25)$ & $-0.37(31)$ & $-0.34(31)$ & $-0.07(22)$ \\
\hline Fraction dry weight of ovary & $0.51(11)$ & $-0.10(14)$ & $0.81 \cdots(15)$ & $0.74 \cdots(15)$ & $0.00(13)$ \\
\hline Fraction dry weight of egg & $0.49(11)$ & $-0.02(22)$ & $0.17(28)$ & $0.16(28)$ & $0.25(20)$ \\
\hline Larval length & $0.04(11)$ & $0.54 \cdots(25)$ & $0.15(25)$ & $0.00(25)$ & $0.37(22)$ \\
\hline Larval weight & $-0.96 \cdots(5)$ & $0.69^{\cdots}(15)$ & $0.08(15)$ & $-0.40(15)$ & $0.18(13)$ \\
\hline Fecundity & - & $-0.01(11)$ & $0.10(11)$ & $0.58(11)$ & $-0.43(11)$ \\
\hline Egg weight & $0.01(11)$ & - & $0.21(25)$ & $-0.06(25)$ & $0.22(22)$ \\
\hline Fertility & $0.10(11)$ & $0.21(25)$ & - & $0.80 \cdots(31)$ & $0.10(22)$ \\
\hline Viable hatch & $0.58(11)$ & $-0.06(25)$ & $0.80^{\cdots} \cdot(31)$ & - & $-0.38(22)$ \\
\hline Survival & $0.43(11)$ & $0.22(22)$ & $0.10(22)$ & $-0.38(22)$ & - \\
\hline
\end{tabular}

ductive rate (Table 2). Little variability in size-specific ovarian weight was observed over the spawning season of winter flounder. Similarly, Tanasichuk \& Ware (1987) found that size-specific ovarian weight of Pacific herring remained remarkably constant over years and between areas.

Given a set amount of mass to devote to reproduction, a change in either egg size or fecundity will result in a corresponding change in the other variable, since these variables are related by the equation:

Reproductive rate $\left(\mathrm{g} \mathrm{yr}^{-1}\right)=$ egg weight $\times$ fecundity

Female size appeared to affect the partitioning of the reproductive mass into individual eggs as estimated by egg size and fecundity (Table 3). This is in agreement with an earlier observation that $3 \mathrm{yr}$ old Pseudopleuronectes americanus produced smalier eggs than did age 4 or 5 fish (Topp 1968). Topp (1968), however, did not observe a significant correlation between female size and ovum size. This may have resulted from asynchronous ripening, as suggested by Topp (1968), or from differences in spawning time, as suggested by our data. Unlike size-specific ovarian weight that showed little variability over the spawning season, egg size and fecundity varied considerably over the spawning season in Narragansett Bay (Tables 2 \& 3).

Seasonal shifts in egg size have been reported for a variety of species that spawn at different locations at different times of the year, notably plaice and herring (Simpson 1959, Blaxter \& Hempel 1963, Cushing 1967. Bagenal 1971). Several authors (Cushing 1967. Bagenal 1971) have suggested that this shift in egg size is related to areal changes in the timing of the production cycle. Similar changes in egg size and fecundity have been demonstrated on an interannual scale for Pacific herring (Tanasichuk \& Ware 1987). These authors linked this change in fecundity and egg size to water temperatures 60 to $90 \mathrm{~d}$ prior to spawning. In this paper we demonstrate a seasonal change in fecundity and egg weight among winter flounder spawning at a single location. This decrease in egg size and the associated increase in fecundity during the spawning season of winter flounder were not due to a progressive decrease in the size of spawning females, as suggested for plaice (Simpson 1959, Bagenal 1971) and herring (Hay 1985, Tanasichuk \& Ware 1987), or to a reduction in egg size over successive batches of eggs from individual females, as suggested for Atlantic cod Gadus morhua (cited in Knutsen \& Tilseth 1985). Rather, in winter flounder the progressive decrease in egg size over the spawning season appeared to result from a change in the balance between egg size and fecundity among females of all sizes as the spawning season progressed.

At least 2 mechanisms for adjusting the number of oocytes brought to full maturity are possible. These are (1) regulation of recruitment of oocytes to the vitellogenic phase, and (2) resorption of developing oocytes prior to spawning (atresia). Both appear to be operative in winter flounder.

A 3 yr cycle for oocyte maturation has been demonstrated for Pseudopleuronectes americanus (Dunn \& Tyler 1969, Burton \& Idler 1984). Tyler \& Dunn (1976) demonstrated that food ration can affect the number of 
oocytes undergoing maturation in winter flounder, and when faced with a shortage of food, females sacrifice egg production but maintain egg size and body weight. They found no increase in the number of oocytes undergoing resorption among females at low rations, although $10.4 \%$ of yolk-bearing oocytes were found to be atretic. They deduced that recruitment of oocytes must have been affected

Several lines of evidence suggest that female fish initiate development of more oocytes than are brought to full maturation. Pre-ovulatory atresia has been observed in several species (Bowers \& Holliday 1961, Polder 1961) including Pseudopleuronectes americanus (Dunn \& Tyler 1969, Tyler \& Dunn 1976). Blaxter \& Holliday (1963) and Tanasichuk \& Ware (1987) have suggested that the maximum number of oocytes is adjusted downward in response to environmental factors. The actual number brought to full maturity and spawned may be determined as late as 20 to $30 \mathrm{~d}$ prior to spawning in Pacific herring (Hay 1985). Tanasichuk \& Ware (1987) presented data for the same species suggesting that water temperature 60 to $90 \mathrm{~d}$ prior to spawning was critical in determining the number of oocytes brought to maturity. They suggested that water temperature during this 'decisive period' acts through its effect on gonadotropin levels, with warm years resulting in higher fecundity and smaller egg size.

Our data on winter flounder Pseudopleuronectes americanus are not wholly consistent with Tanasichuk \& Ware's hypothesis of a 'decisive period' for vitellogenesis 60 to $90 \mathrm{~d}$ prior to spawning, suggesting that the same mechanism may not operate on an interannual basis in winter flounder. In Narragansett Bay the winter flounder spawning season extends from January to April. Examination of $14 \mathrm{yr}$ of sea-surface temperature records from the NOAA National Ocean Service tide station at Newport, Rhode Island, indicated that the temperature minimum usually occurs between the last week of January and the second week of February (range in Julian days $=20$ to 50 ). The 'decisive period' 60 to $90 \mathrm{~d}$ prior to spawning of winter flounder would occur during the descending portion of the annual temperature cycle. Early-spawning fish should, on average, experience warmer temperatures 60 to $90 \mathrm{~d}$ prior to spawning during the 'critical period' than do later-spawning fish, even though water temperatures are lower at spawning. In apparent conflict with the 'decisive period' hypothesis, early-spawning winter flounder, which would on average experience warmer water temperatures 60 to $90 \mathrm{~d}$ prior to spawning, produce larger eggs and have lower relative fecundity than do late-spawning fish. It is possible, however, that the later-spawning fish remain in warmer water offshore during the 'decisive period'. Our data on experimental manipulation of water temperature, beginning $50 \mathrm{~d}$ prior to spawning in winter flounder (Buckley et al. 1990), suggest that water temperature closer to the time of spawning may be critical in determining larval size and viability in winter flounder.

Several authors have published estimates of the fecundity of Pseudopleuronectes americanus as a function of female size (Saila 1963, Topp 1968, Kennedy \& Steele 1971); however, none considered an effect of spawning time. While female weight explained most $(90 \%)$ of the variability in fecundity observed in our data (Table 2), the residuals increased with spawning date. Addition of spawning time as a second independent variable significantly improved the regression, explaining an additional $4 \%$ of the variability. Our estimates of egg production of winter flounder from Narragansett Bay are in close agreement with those of Saila (1963) for winter flounder collected 30 yr earlier in Narragansett Bay and slightly lower than those of Topp (1968) for fish from Massachusetts Bay (Table 8). The weight-fecundity curves published by Saila (1963) for Narragansett Bay and by Kennedy \& Steele (1971) for Conception Bay, Newfoundland, were not statistically different. Our fecundity estimates for early and late spawners encompass estimates based on Saila's female weight-fecundity relation.

Assessment of the spawning condition and reproductive capacity of Pseudopleuronectes americanus is confounded by the prolonged period of gametogenesis (Burton \& Idler 1984). The possible downward adjustment in the number of recruited oocytes suggests that care should be exercised in using fecundity estimates based on counts of maturing oocytes far in advance of spawning in winter flounder.

The increasing portion of body weight devoted to reproduction in larger individuals (increase in GSI with

Table 8. Pseudopleuronectes americanus. Fecundity estimates (no. eggs female ${ }^{-1}$ ) for winter flounder from Narragansett Bay in 1958 (Saila 1963) and 1988 (present study), and Massachusetts Bay in 1966 (Topp 1968). JD: Julian Day

\begin{tabular}{|c|c|c|c|c|}
\hline \multirow[t]{3}{*}{ Female weight } & \multirow{3}{*}{$\frac{\text { Massachusetts Bay }}{1966}$} & \multicolumn{3}{|c|}{ Narragansett Bay } \\
\hline & & \multirow[t]{2}{*}{1963} & \multicolumn{2}{|c|}{1988} \\
\hline & & & Early (JD 31) & Late (JD 90) \\
\hline $250 \mathrm{~g}$ & 422000 & 252000 & 116000 & 383000 \\
\hline $1000 \mathrm{~g}$ & 1851000 & 1219000 & 1109000 & 1377000 \\
\hline
\end{tabular}


female size; Table 2) has been observed in several species (Ware \& Tanasichuk 1989). An interesting question relates to how this surplus is partitioned between production of larger eggs and production of more eggs. The GSI of a typical large winter flounder (1000 $\mathrm{g}$ wet weight) is $39 \%$, compared to $27 \%$ in a typical small one $(260 \mathrm{~g})$ (Table 2 ). The extra $12 \%$ of the body weight of the large fish directed toward reproduction represents $120 \mathrm{~g}$ of surplus production and is independent of spawning time. Among early spawners (Julian Day 32), $83 \mathrm{~g}$ or roughly two-thirds of the surplus goes to production of larger eggs, and $40 \mathrm{~g}$, or roughly one-third, is directed toward producing more eggs. Among late spawners an even larger portion of the surplus in large females goes to production of larger eggs.

Several notable observations on batch spawning and ovarian dry weight were made during the course of this study. Individual winter flounder appeared to produce and spawn several batches of ripe eggs over several days before becoming completely spent. Dry matter, as a percentage of wet weight, made up $16 \%$ of the unfertilized egg, $21 \%$ of the ovary after 1 hand-stripping and $12.6 \%$ of the fully spent ovary. These changes in the concentration of dry matter in the ovary point to limitations in the use of vital statistics based solely on wet weight measurements. An inverse correlation was observed between the fraction of the ovary spawned after 1 hand-stripping and both the concentration of dry matter in the partially spent ovary and the size of the female. Apparently the concentration of dry matter is highest just prior to the initial hydration. A portion of the mature oocytes hydrate over several days and are spawned, resulting in a reduction in the density of the partially spent ovary compared to the initial prehydration condition. This cycle of hydration and spawning is repeated over several days until the fish is spent. At this point the concentration of dry matter in the ovary is at a minimum. Dry matter remaining in the fully spent ovary represents $10.6 \%$ of the dry weight of the ovary just prior to spawning. No difference in the rates of fertilization or viable hatch was observed among batches of eggs produced by the same female.

Our data on fertilization, viable hatch, and survival rates suggest that female size and spawning time can have important effects on these variables. For both fertility and hatch rate, the interaction of female size and spawning time was significant. Embryos produced early in the season appeared to have a survival advantage over those produced later in the season (Table 6). In most cases embryos produced by small, late-spawning fish appeared to be at a pronounced disadvantage. Trends in size and viability of eggs produced over the spawning season could contribute to differential survival at later life-history staqes. Differences in the dis- tribution of birth dates estimated from egg production and from otolith analysis of larvae and juveniles have been observed for several species (Methot 1983, Rice et al. 1987). The role of egg quality in these patterns should be considered along with the role of environmental variability.

Fertilization rate, hatch rate and viable hatch rate were highly correlated but unrelated to larval survival rate (Table 7 ). For fish spawned from Narragansett Bay in 1988, we were unable to identify a single property of the unfertilized egg or newly hatched larva that was related significantly to larval survival. The parameters examined included egg dry weight and chemical composition (protein, RNA, and lipid content), and initial length and weight of the newly hatched larva. This is in contrast to larvae from Pseudopleuronectes americanus collected at several locations in Long Island and Narragansett Bay during the 1987 spawning season, where we observed a strong correlation between initial larval size (and chemical content) and survival for the first month of life (Buckley et al. 1991). There are at least 2 possible explanations for this difference in results: (1) in the earlier work a much broader range of initial sizes was observed, and (2) the rearing conditions used in the current work may have minimized the survival advantage of larger larvae over smaller larvae. In this effort, due to very low fertility and hatch rates, we were unable to obtain sufficient larvae from small, latespawning winter flounder to determine larval survival rates. These eggs and yolk-sac larvae were among the smallest produced in 1988. This effectively resulted in an even smaller range in initial larval size for survival trials.

We have described an approach to obtaining vital statistics (reproductive rate, GSI, fecundity) on individual fish while obtaining viable eggs from the same individuals. These eggs can be used for studies of viability and survival potential. Using this approach we have demonstrated that female size and spawning time of winter flounder have important effects on egg size, fecundity and survival potential. Small, late-spawning females produced small eggs and larvae that appeared to have a reduced survival potential.

\section{LJTERATURE CITED}

Bagenal, T L. (1971). The interrelation of the size of fish eggs, the date of spawning and the production cycle. J. Fish Biol. 3: $207-219$

Blaxter, J. H. S., Hempel, G. (1963). The influence of egg size on herring larvae (Clupea harengus L.). J. Cons. perm. int. Explor. Mer 28: 211-240

Blaxter, J. H. S., Holliday, F. G. T (1963). The behavior and physiology of herring and other clupeids. Adv. mar. Biol. 1 261-393

Bowers, A. B. Hollıday, F. G. T (1961). Histological changes in 
the gonad associated with the reproductive cycle of the herring (Clupea harengus L.). Mar. Res. Scot. No. 5: 16 p.

Buckley, L. J. (1980). Changes in ribonucleic acid, deoxyribonucleic acid, and protein content during ontogenesis in winter flounder, Pseudopleuronectes americamus, and the effects of starvation. Fish. Bull. U.S. 77: 703-708

Buckley, L. J., Smigielski, A. S., Halavik, T A., Caldarone, E. M., Burns, B. R., Laurence, G. C. (1991). Winter flounder Pseudopleuronectes americanus reproductive success. I. Among-location variability in size and survival of larvae reared in the laboratory. Mar. Ecol. Prog. Ser, 74: 117-124

Buckley, L. J., Smigielski, A. S., Halavik, T A., Laurence, G. C. (1990). Effects of water temperature on size and biochemical composition of winter flounder Pseudopleuronectes americanus at hatching and feeding initiation. Fish. Bull. U.S. 88: 419-428

Burton, M. P., [dler, D. R. (1984). The reproductive cycle in winter flounder, Pseudopleuronectes americanus (Walbaum). Can. J. Zool. 62: 2563-2567

Cushing, D. H. (1967). The grouping of herring populations. J mar. biol. Ass. U.K. 47: 193-208

Dunn, R. S., Tyler, A. V. (1969). Aspects of the anatomy of the winter flounder ovary with hypotheses on oocyte maturation time. J. Fish. Res. Bd Can. 26: 1943-1947

Gall, G. A. E. (1974). Influence of size of eggs and age of female on hatchability and growth in rainbow trout. Calif. Fish Game 60: 26-36

Hay, D.E. (1985). Reproductive biology of Pacific herring (Clupea harengus pallasi). Can. J. Fish. Aquat. Sci. 42: 111-126

Hempel, G., Blaxter, J. H. S. (1967). Egg weight in Atlantic herring (Clupea harengus L.). J. Cons. perm. int. Explor Mer 31. 170-195

Kazakov, R. V. (1981). The effect of the size of Atlantic salmon, Salmo salar L., eggs on embryos and alevins. J. Fish Biol. 353-360

Kennedy, V S., Steele, D. H. (1971). The winter flounder (Pseudopleuronectes americanus) in Long Pond, Conception Bay, Newfoundland. Can. J. Fish. Aquat. Sci. 28: $1153-1165$

Knutsen, G. M., Tilseth, S. (1985). Growth development, and feeding success of Atlantic cod larvae Gadus morhua related to egg size. Trans. Am. Fish. Soc. 114: 507-511

Methot, R. D., Jr. (1983). Seasonal variation in survival of larval northern anchovy, Engraulis mordax, estimated from age distribution of juveniles. Fish. Bull. U.S. 81: 741-750

This article was presented by $K$. Sherman, Narragansett, Rhode Island, USA
Miller, T. J., Crowder, L. B., Rice, J. A., Marschall, E. A. (1988) Larval size and recruitment mechanisms in fishes: toward a conceptual framework. Can. J. Fish. Aquat. Sci. 45: $1657-1670$

Polder, J. J. W (1961). Cyclic changes in testes and ovary related to maturity stages in the North Sea herring (Clupea harengus L.). Archs néerl. Zool. 14: 45-60

Rice, J. A., Crowder, L. B., Holey, M. E. (1987). Exploration of mechanisms regulating larval survival in Lake Michigan bloater: a recruitment analysis based on characteristics of individual larvae. Trans. Am. Fish. Soc. 116: 703-718

Rogers, B. A., Westin, D. T (1981). Laboratory studies on effects of temperature and delayed initial feeding on development of striped bass larvae. Trans. Am. Fish. Soc. 110: $100-110$

Saila, S. B. (1963). The contribution of estuaries to the offshore winter flounder fishery in Rhode Island. Proc. Gulf Carrib. Fish. Inst. 14: 95-109

SAS Institute Inc. (1985). SAS/STAT guide for personal computers, Version 6 edn. SAS Institute, Inc., Cary, North Carolina

Simpson, A. C. (1959). The spawning of plaice in the North Sea. Fishery Invest., Lond. (Series 2) 22: 1-111

Tanasichuk, R. W., Ware, D. M. (1987). Influence of interannual variations in water temperature on fecundity and egg size in Pacific herring (Clupea harengus pallasi). Can. J. Fish. Aquat. Sci. 44: 1485-1495

Topp, R. W. (1968). An estimate of the fecundity of winter flounder, Pseudopleuronectes americanus. J. Fish. Res. Bd Can. 25: 1299-1302

Tyler, A.V., Dunn, R. S. (1976). Ration, growth, and measures of somatic and organ condition in relation to meal frequency in winter flounder, Pseudopleuronectes americanus, with hypotheses regarding population homeostasis. J. Fish. Res. Bd Can. 33: 63-75

Ware, D. M. (1985). Life history characteristics, reproductive value, and resilience of Pacific herring (Clupea harengus pallasi). Can. J. Fish. Aquat. Sci. 42 (Suppl. 1): 127-137

Ware, D. M., Tanasichuk, R. W. (1989). Biological basis for maturation and spawning waves in Pacific herring (Clupea harengus pallasi). Can. J. Fish. Aquat. Sci. 46 $1776-1784$

Zastrow, C. E., Houde, E. D., Saunders, E. S. (1988). Quality of striped bass (Morone saxatili) eggs in relation to river source and female size. ICES 1988 ELH/No. 60

Manuscript first received: December 3, 1990

Revised version accepted: May 21, 1991 